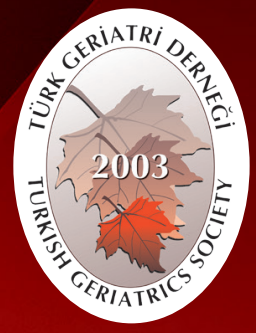

Turkish Journal of Geriatrics

DOI: $10.31086 /$ tjgeri.2019150568

2019;22 (1):18-24

- Süheyla ABITAĞAOĞLU1 D

- Öznur DEMIROLUK ${ }^{1}$ D

- Ceren KÖKSAL ${ }^{1}$ (D)

- Duygu SEZGIN ${ }^{1}$ (D)

- Güldem TURAN ${ }^{1}$ (D)

\title{
TRANSITION TO HOME MECHANICAL VENTILATION FOR GERIATRIC PATIENTS WITH PROLONGED WEANING
}

\section{Abstract}

Introduction: Demographic changes have resulted in increasing numbers of geriatric patients needing respiratory support in intensive care units. Conversely, these patients are faced with an increased risk of weaning failure and can be discharged with home mechanical ventilation. This study aimed to investigate the discharge status and home mechanical ventilator use of the elderly patients who experienced weaning failure.

Materials and Method: We retrospectively investigated the data of 51 patients older than 65 years who required home mechanical ventilator prescription due to delayed mechanical ventilation during their treatment in intensive care unit between January 2016 and January 2018.

Results: The patients' mean age was $78.33 \pm 8.12$ years. Twenty-six patients $(51 \%)$ switched to home mechanical ventilator, 12 weaned and 13 died before switching to home mechanical ventilator. Eleven patients $(42.3 \%)$ were discharged with home mechanical ventilator and 15 $(57.7 \%)$ were spontaneously breathing. Four patients were prescribed palliative care, 3 were sent home, 3 to a nursing home, 2 to the hospital ward and 14 to a secondary intensive care unit. After discharge, 9 patients were re-admitted to the intensive care unit and 12 of the 15 patients we contacted, died within 1 year.

Conclusion: Although the estimated mortality rate is high in geriatric patients in intensive care units, our study showed that the rate of discharge with a home mechanical ventilator was also high in these patients. Considering the prolonged length of stay in intensive care unit, we think that it is important to plan the discharge with a home mechanical ventilator in this patient group.

Keywords: Geriatrics; Ventilators, Mechanical; Weaning; Patient discharge

ARAŞTIRMA

CORRESPONDANCE

Süheyla ABITAĞAOĞLU

University of Health Sciences, Fatih Sultan

Mehmet Health Research and Application Center

Anesthesiology and Reanimation Department,

istanbul, Turkey

Phone: 02165783000

e-mail: suheylaatay81@gmail.com

Received: $31 / 08 / 2018$

Accepted: 05/02/2019

University of Health Sciences, Fatih Sultan Mehmet Health Research and Application Center, Anesthesiology and Reanimation Department, İstanbul, Turkey

\section{MEKANIK VENTILATÖRDEN AYRILMA SÜRECI UZAMIS GERIATRI YAŞ GRUBUNDAKI HASTALARDA EV TIPI VENTILATÖRE GEÇIŞ}

\section{Öz}

Giriş: Toplumdaki demografik değişiklikler ile geriatri yaş grubundaki hastalarda yoğun bakım yatışı ve solunum desteği ihtiyacı artmaktadır. Öte yandan bu hastalar mekanik ventilatörden ayrılamama riski ile karşı karşıyadır ve ev tipi ventilatör ile taburcu edilebilirler. Bu çalışmanın amacı yaşlı hastaların yoğun bakımdan taburculuk durumlarını ve ev tipi ventilatör kullanımlarını incelemektir.

Gereç ve Yöntem: Ocak 2016-Ocak 2018 tarihleri arasında yoğun bakımda tedavisi yapılan ve uzamış mekanik ventilasyon nedeniyle ev tipi ventilatör reçete edilen 65 yaş üstü 51 hastanın verileri retrospektif olarak incelendi.

Bulgular: Ortalama yaş $78.33 \pm 8.12$ idi. Hastaların 26 'sında (\%51) ev tipi ventilatöre geçilirken; ev tipi ventilatöre geçilmeden önce 12 hasta mekanik ventilatörden ayrıldı, 13 hasta ise kaybedildi. Hastalardan $11^{\prime} \mathbf{i}(\% 42.3)$ ev tipi ventilatör ile, $15^{\prime} i(\% 57.7)$ spontan solunum ile taburcu edildi. Dört hasta palyatif bakım ünitesine, 3 hasta eve, 3 hasta bakımevine, 2 hasta servise ve 14 hasta ise alt düzey yoğun bakıma ünitesine çıkarıldı. Taburculuk sonrası takiplerde 15 hasta yakınına ulaşılabildi; 9 hastanın tekrar yoğun bakım ünitesine yatıııldığı ve toplamda 12 hastanın ilk yıl içinde kaybedildiği öğrenildi.

Sonuç: Yoğun bakım ünitesindeki geriatrik hastalarda öngörülen mortalite oranı yüksek olmasına rağmen, çalışmanın sonuçlarında hastaların ev tipi ventilatör ile taburcu olma yüzdeleri de yüksek bulunmuştur. Bu hasta grubunda yoğun bakım yatış sürelerinin uzun olduğu göz önüne alınarak, ev tipi mekanik ventilatör ile taburculuk planlanmasının önemli olduğu düşünülmektedir.

Anahtar sözcükler: Yaşlılık; Mekanik ventilatör; Ventilatörden ayırma; Hasta taburculuğu 


\section{INTRODUCTION}

As populations age, the number of elderly patients in intensive care units (ICUs) needing respiratory support increases. With increasing age, the parenchymal and distal airways change, compliance declines, diaphragmatic strength decreases and respiratory drive changes, thus resulting in an increase in the risk of respiratory failure development (1). Simultaneously, elderly patients are faced with an increased risk of weaning failure and extended mechanical ventilation (2).

Some patients with weaning failure have to continue their lives with mechanical ventilation. The number of ventilatory-assisted patients living at home continues to increase. The prevalence of home mechanical ventilation (HMV) has been estimated to be 6,6 per 100,000 individuals in Europe (3). Advances in technology and health care delivery along with the patients' desire to preserve their quality-of-life and integrate into the community contribute to this increase (4). Discharging patients with home mechanical ventilator is important for the rational use of ICUs and to save health care systems costs.

Therefore, this study aimed to retrospectively investigate the discharge status, destination and HMV use of the elderly patients who experienced weaning failure during treatment period in ICU.

\section{MATERIALS AND METHOD}

We retrospectively investigated the data of patients older than 65 years who required HMV prescription due to delayed mechanical ventilation during their treatment in ICU at the University of Health Sciences Fatih Sultan Mehmet Health Research and Application Center between January 2016 and January 2018. After approval by our hospital's Scientific Studies Board (FSM SSB ref No: 2017/2134), we retrospectively investigated the patients' data. We recorded age, gender, acute physiology and chronic health evaluation (APACHE II) scores, Glasgow Coma Scale (GCS) scores and ejection fraction (EF\%) at the time of admission as well as ICU admission and respiratory insufficiency causes, ICU stay, mechanical ventilation duration, time to tracheostomy, time to switch to HMV and HMV adaptation process duration. At the time of ICU discharge, we documented the GCS scores, ventilation modes and discharge destination.

The relationship between mortality and age, APACHE II, GCS during admission, cause of intensive care admission, cause of respiratory failure, presence of comorbidities and duration of mechanical ventilation were evaluated. Age, APACHE II, GCS during admission, cause of respiratory failure, duration of mechanical ventilation, comorbidities, length of stay in the intensive care unit (ICU), time of tracheostomy and discharge GCS parameters were evaluated for their effect on transition to home mechanical ventilation. Also patients were divided into three groups based on how they were discharged: discharged with home mechanical ventilator; discharged with spontaneous respiration after home mechanical ventilator was provided and death in the ICU. The three groups were compared in terms of age, APACHE II, admission GCS, comorbidity, duration of mechanical ventilation and length of stay in the ICU.

After discharge, the family members of the patients were contacted for a telephonic interview to obtain information about the current status of the patients.

The data were examined by Shapiro-Wilk test whether it presents normal distribution. Descriptive statistics were given as mean, standard deviation and frequency. Non-normally distributed data were compared using KruskalWallis test. Categorical variables were compared using Pearson's chi-squared and Fisher-FreemanHalton tests. Backward Cox proportional hazards 
regression was used to assess the associations of age, APACHE II, GCS, aetiology of respiratory failure, duration of mechanical ventilation, comorbidities and causes of ICU admission with time to death. Factors such as age, APACHE II, GCS score, aetiology of respiratory failure, duration of mechanical ventilation, comorbidities, duration of ICU stay, GCS score on discharge, day of tracheostomy and causes of ICU admission affecting HMV were identified with backward logistic regression analysis. A p-value of $<0.05$ was considered significant. Statistical analyses were performed with IBM SPSS ver.23.0 (IBM Corp. Released 2015. IBM SPSS Statistics for Windows, Version 23.0. Armonk, NY: IBM Corp.).

\section{RESULTS}

A total of 51 patients were included in the study; 21 women (41.2\%) and 30 men (58.8\%). The demographic data of the patients are shown in Table 1. Twenty-eight patients (54.9\%) were admitted to the ICU with primary- and 23 (45.1\%) with secondary respiratory failures. Most patients had several comorbidities; Table 2 shows the comorbidity frequency and causes of ICU admission.

Twelve of the patients weaned and 13 patients died before switching to HMV. Twenty-six (51\%) of the patients switched to HMV. Table 3 summarises the data during follow-up and aetiology of the patients requiring reinitiation of $\mathrm{MV}$ after HMV.

Twenty-six patients were discharged from the ICU. Eleven patients (42,3\%) were discharged with home mechanical ventilation and 15 patients $(57,7 \%)$ were discharged with spontaneous breathing. The mean GCS score of the patients at discharge was $8,9 \pm 3,2$. Among the discharged patients, $4(15,3 \%)$ were transferred to palliative care, $3(11,5 \%)$ to their homes, $3(11,5 \%)$ to a nursing home, $2(7,6 \%)$ to a hospital ward and $14(53,8 \%)$ to a secondary ICU. We found no differences between the aetiology of respiratory failure and the ventilation type during discharge or the current status of the patients (Table 4). Family members of 15 of the 26 discharged patients could be contacted by phone. After discharge, 9 patients needed ICU re-hospitalisation and 12 of 15 patients died and the mean time to death after discharge was $107.7 \pm 122.4$ days. Two patients were able to spontaneously breathe and one required $\mathrm{HMV}$.

The relationship between mortality and age, APACHE II, GCS during admission to ICU, cause of ICU admission, cause of respiratory failure, presence of comorbidities and duration of mechanical ventilation were evaluated. A positive correlation was found between APACHE II values and mortality rates $(p=0.05)$. The mortality rate decreased as the duration of mechanical ventilation increased $(p=0.01)$. There was no significant correlation between mortality and other parameters.

It was found that patients' age, APACHE II, GCS at admission, cause of respiratory failure, duration of mechanical ventilation, comorbidities, length of stay in the ICU, time of tracheostomy and GCS on discharge from the ICU did not have any effect on the transition to home mechanical ventilation.

No significant difference was found among the patients discharged with home mechanical ventilation, those discharged with spontaneous respiration after home mechanical ventilator was provided or those who died in the ICU in terms of age, APACHE II, GCS during ICU admission, comorbidities, duration of mechanical ventilation and length of stay in the ICU (Table 5). 
Table 1. Demographical data of the patients.

\begin{tabular}{|l|r|r|}
\hline Characterisctics & Min-Max & Mean \pm sd \\
\hline Age (years) & $65-93$ & $78.33 \pm 8.12$ \\
\hline Apache II Score & $10-36$ & $23.96 \pm 5.99$ \\
\hline Baseline GCS Score & $3-15$ & $7.93 \pm 3.74$ \\
\hline EF (\%) & $20-65$ & $54.84 \pm 10.04$ \\
\hline
\end{tabular}

Table 2. Causes of ICU admission and comorbidity distribution of the patients.

\begin{tabular}{|l|r|}
\hline & Number of patients (\%) \\
\hline Cause of ICU admission & $16(31.4)$ \\
Cerebrovascular disease & $6(11.8)$ \\
Cardiopulmonary arrest & $15(29.4)$ \\
Dyspnoea & $5(9.8)$ \\
Postoperative & $2(3.9)$ \\
Sepsis & $4(7.8)$ \\
Pneumonia & $2(3.9)$ \\
Status epilepticus & $1(2)$ \\
Pancreatitis & \\
\hline Number of comorbidities (\%) & $1(2)$ \\
None & $5(9.8)$ \\
1 & $14(27.5)$ \\
2 & $13(25.5)$ \\
3 & $15(29.4)$ \\
4 & $3(5.9)$ \\
\hline
\end{tabular}

Table 3. Data of the patients during ICU follow-up.

\begin{tabular}{|l|r|}
\hline Duration of ICU stay (days) & $57.7 \pm 36.5$ \\
\hline Duration of MV (days) & $41 \pm 22.8$ \\
\hline Day of tracheostomy & $16.7 \pm 10.6$ \\
\hline Days to switch to HMV & $50.3 \pm 28.5$ \\
\hline Duration of HMV adaptation process (days) & $3.4 \pm 3.05$ \\
\hline Number of patients switching to MV (\%) & $13(50)$ \\
Ventilatory-associated pneumonia (\%) & $3(7.7)$ \\
Adaptation problems (\%) & $3(23.1)$ \\
Hemodynamic disturbances (\%) & $6(46.2)$ \\
Respiratory disturbances (\%) & $3(23.1)$ \\
\hline Mortality in ICU (\%) & $25(49)$ \\
\hline
\end{tabular}


Table 4. Effect of the aetiology of respiratory failure on discharge ventilation and current status of the patients.

\begin{tabular}{|c|c|c|c|}
\hline \multirow[b]{2}{*}{ Characteristics } & \multicolumn{2}{|c|}{ Aetiology of Respiratory Failure } & \multirow[b]{2}{*}{$\mathrm{p}$} \\
\hline & $\begin{array}{r}\text { Primary } \\
\mathrm{n}(\%) \\
\end{array}$ & $\begin{array}{r}\text { Secondary } \\
n(\%)\end{array}$ & \\
\hline Discharge ventilation & & & a1.000 \\
\hline HMV & $5(41.7 \%)$ & $6(42.9 \%)$ & \\
\hline Spontaneous & $7(58.3 \%)$ & $8(57.1 \%)$ & \\
\hline Current status & & & b0.262 \\
\hline Alive & $3(12.5 \%)$ & $-(-)$ & \\
\hline Ex & $21(87.5 \%)$ & $16(100 \%)$ & \\
\hline
\end{tabular}

${ }^{a}$ Continuity (Yates)

${ }^{b}$ Fisher's Exact Test n: number of patients

Table 5. Comparison of age, APACHE II, GCS, comorbidity, mechanical ventilation and length of stay in ICU according to patient discharge status.

\begin{tabular}{|l|r|r|r|r|}
\hline Characteristics & $\begin{array}{r}\text { Discharge with } \\
\text { HMV }\end{array}$ & $\begin{array}{r}\text { Spontaneous } \\
\text { Respiration }\end{array}$ & Exitus & p \\
\hline Age (years) & $79.5 \pm 9.1$ & $75.4 \pm 7.8$ & $78.6 \pm 7.8$ & 0.187 \\
\hline APACHE II & $23 \pm 4.5$ & $21.8 \pm 5.5$ & $25.2 \pm 6.3$ & 0.066 \\
\hline GCS at admission to ICU & $8.7 \pm 4.4$ & $6.7 \pm 3.1$ & $8.2 \pm 3.6$ & 0.546 \\
\hline Comorbidities (n) & $3 \pm 1.3$ & $2.3 \pm 1.3$ & $3.1 \pm 0.9$ & 0.121 \\
\hline $\begin{array}{l}\text { Duration of mechanical ventilation } \\
\text { (days) }\end{array}$ & $40.8 \pm 16.2$ & $32.6 \pm 17.4$ & $45.6 \pm 27.5$ & 0.316 \\
\hline Length of stay in ICU (days) & $62.8 \pm 22.7$ & $44.7 \pm 20.2$ & $64 \pm 47.9$ & 0.156 \\
\hline
\end{tabular}

Kruskal-Wallis test

\section{DISCUSSION}

The geriatric population requiring hospitalisation and ICU admission has increased due to the increases in life expectancy (5). Geriatric patients in the ICU generally require mechanical ventilation due to respiratory insufficiency. Multiple comorbidities and muscle weakness are frequent in this patient population. Under these circumstances, the weaning process gets prolonged and sometimes they become dependent on mechanical ventilation $(6,7)$. Chronic respiratory failure due to various reasons and requiring continuous mechanical ventilation results in longer intensive care unit and this is not conformable for rational use of third stage intensive care units. The ideal care for such patients is following-up at intermediate care units. However, this increased need cannot be met with the existing units. For this reason, the patients can be discharged with HMV to maintain life quality at home. In our previous study, we observed that the weaning times were prolonged in geriatric patients and $54 \%$ of the patients could not be weaned (2). We have developed our clinical practice to encourage home mechanical ventilator use as a normal practice for geriatric patients with chronic 
respiratory insufficiency with the cooperation of the patient's relatives to carry out the next processes at home.

We have documented 2-year follow-up data from our geriatric patients undergoing HMV procedures to evaluate the results of this practice.

There are several factors that affect the weaning and extubation processes. One of the risk factors for extubation failure is advanced age $(8,9)$. Age also increases ICU mortality. Increased comorbidity and ICU complications increase the mechanical ventilation duration; moreover, longer mechanical ventilation increases mortality $(9,10)$. According to the regression analysis performed in our study, mortality decreased as the duration of mechanical ventilation increased. Contrary to expectations, there was a negative relationship between the duration of mechanical ventilation and mortality, to which our patients' death due to advanced age can be attributed. In the geriatric age group, the rapid deterioration of physiological balance in case of an acute disease may cause the patient to have limited time to respond to intensive care treatment. Geriatric patients who cannot survive this acute phase can be lost in the early stages of intensive care. We encounter prolonged mechanical ventilation periods due to advanced age-related muscle weakness in geriatric patients who survive this period. Therefore, we believe that there was a negative correlation between prolongation of mechanical ventilation and mortality rate in our patient group.

Despite the prolonged mechanical ventilation $(41 \pm 22,8$ days), $29 \%$ of the 51 patients were successfully weaned, $25 \%$ of the patients died before switching to HMV and $49 \%$ died in the ICU. In a study, the mortality of elderly mechanically ventilated ICU patients was found to be 53\% (11), which is similar to our results.

Yatabe et al demonstrated that postoperative patients had lower in-hospital mortality than nonsurgical patients (12). In our study, we compared the effect of the aetiology of respiratory failure on mortality and found that the aetiology of respiratory failure did not influence the patients' outcome in terms of mortality. These results suggest that comorbidities play a more important role on mortality than the aetiology of respiratory failure in elderly patients. As expected in the geriatric age group, a significant correlation was found between APACHE II values and mortality in our study.

In the study, we included elderly patients who were prescribed HMV after prolonged weaning. After managing the acute illness in ICU, these elderly multi-morbid patients often require a longterm ventilator support (13). HMV is a good choice to decrease in-hospital infections in these fragile patients and this approach increases their integration back to society. When we looked at what is the most important factor in transition to home mechanical ventilation, we found that there was no significant correlation among age, APACHE II, admission GCS, cause of respiratory failure, duration of mechanical ventilation, comorbidities, length of stay in the ICU, tracheotomy opening time and discharge GCS parameters evaluated in our study. However, we found variable practices in the literature in terms of HMV prescriptions for geriatric patients, and a previous study has shown that patients aged $>75$ years had benefits from HMV (14). In our study, the adaptation period of the patients to HMV was $3,4 \pm 3,05$ days, and no problems were encountered during the transition to HMV.

Galiatsatos et al indicated that the length of ICU stay affects the destination of discharge (15). In our study, the mean duration of ICU stay was 57 days and the percentage of patients discharged home was lower than that of patients discharged to medical units (wards, palliative care and secondary ICU). In our study, no significant difference was found among the three groups of patients based on discharge type, patients discharged with home mechanical ventilation, those discharged with spontaneous respiration after home mechanical ventilator was provided or those who died in the ICU, in terms of age, APACHE II, GCS during ICU 
admission, comorbidities, duration of mechanical ventilation and length of stay in the ICU. After discharge, 9 patients were re-admitted to the ICU and 12 of 15 patients that we could contact died within 1 year. The geriatric ICU population has a high long-term mortality when compared to the non-geriatric population (16). Fagon stated that post-discharge deaths in elderly patients are higher within the first 3 months (17), whereas Lieberman et al showed that most of the deaths were within the first 6 months after discharge (18). Consistent with these studies, we found the mean time of death was 107 days after discharge.

\section{REFERENCES}

1. El Solh AA, Ramadan FH. Overview of respiratory failure in older adults. J Intensive Care Med 2006;21(6):345-51. (PMID:17095498).

2. Turan G, Ar AY, Kuplay $Y Y$, Abitağaoğlu S, Karip CŞ, Öksüz M. Weaning in geriatric patients: A retrospective clinical study. Turkish Journal of Geriatrics 2017;20(4):264-70.

3. El Solh AA, Bhat A, Gunen H, Berbary E. Extubation failure in the elderly. Respir Med 2004;98(7):661-8. (PMID:15250233).

4. Rose L, McKim DA, Katz SL, et al. Home Mechanical Ventilation in Canada: A National Survey. Respir Care 2015;60(5):695-704. (PMID:25587173).

5. Bozkurt AP, Çavuşoğlu P, Karaören G, et al. Effectiveness of scoring in outcome prediction of elderly patients in intensive care unit. Turkish Journal of Geriatrics 2016;19(3):133-8.

6. Lai CC, Ko SC, Chen CM, Weng SF, Tseng KL, Cheng $\mathrm{KC}$. The outcomes and prognostic factors of the very elderly requiring prolonged mechanical ventilation in a single respiratory care center. Medicine (Baltimore) 2016;95(2):e2479. (PMID:26765452).

7. Sevransky JE, Haponik EF. Respiratory failure in elderly patients. Clin Geriatr Med 2003;19(1): 205-24. (PMID:12735123).

8. Carson SS. The epidemiology of critical illness in the elderly. Crit Care Clin 2003;19(4):605-17. (PMID:14601710).

9. Cheng AC, Cheng KC, Chen CM, Hsing SC, Sung MY. The outcome and predictors of failed extubation in intensive care patients-the elderly is an important predictor. Int J Gerontol 2011;5(4):206-11.

10. Pappa E, Pavlou H, Eforakopoulou M. Factors affecting mechanical ventilation in ICU elderly
Although the estimated mortality rate is high in geriatric patients in ICUs due to advanced age, high APACHE score, low GCS, high comorbidity, prolonged mechanical ventilation and length of stay in ICU, our study showed that the rate of discharge with a home mechanical ventilator was also high in these patients. We think that it is important to plan the discharge with a home mechanical ventilator by considering the prolonged length of stay in ICU in this patient group.

patients. Intensive Care Med Exp 2015 3(Suppl 1):A660.

11. Lieberman D, Nachshon L, Miloslavsky $O$, et al. Elderly patients undergoing mechanical ventilation in and out of intensive care units: a comparative, prospective study of 579 ventilations. Crit Care 2010;14(2):R48. (PMID:20353552).

12. Yatabe T, Nishigaki A, Tamura T, Yokoyama M. Mortality and physical status at hospital discharge in Japanese elderly critically ill patients: a singlecenter retrospective study. JA Clin Rep 2018;4(1):1. (PMID:29457111)

13. Kastrup M, Tittmann B, Sawatzki T, et al. Transition from in-hospital ventilation to home ventilation: process description and quality indicators. Ger Med Sci. 2017 19;15:Doc18. (PMID:29308061).

14. Escarrabill J, Tebé C, Espallargues M, Torrente E, Tresserras R, Argimón JM. Variability in home mechanical ventilation prescription. Arch Bronconeumol 2015;51(10):490-5. (PMID:25618455).

15. Galiatsatos P, Friedlander T, Dababneh D, et al. 1-year survival of subjects discharged from a long-term chronic ventilator unit. Respir Care 2017;62(10):128490. (PMID:28720672).

16. Schrøder MA, Poulsen JB, Perner A. Acceptable long-term outcome in elderly intensive care unit patients. Dan Med Bull 2011;58(7):A4297.

17. Fagon JY. Acute respiratory failure in elderly. Crit Care 2006;10:151. (PMID:16887005).

18. Lieberman D, Nachshon L, Miloslavsky O, Dvorkin $V$, Shimoni A, Lieberman D. How do older ventilated patients fare? A survival/functional analysis of 641 ventilations. J Crit Care 2009;24(3):340-6. (PMID:19664523). 